\title{
Association of CYP1A1 (cytochrome P450) MspI polymorphism in women with endometriosis
}

\author{
A.M. Barbosa ${ }^{1,2}$, S.R. de Souza ${ }^{1,2}$, A.B. Frare ${ }^{1,2}$, R.C. Costa e Silva ${ }^{1,2,3}$, \\ I.R. da Costa ${ }^{1,2,3}$, K.S. Freitas e Silva ${ }^{1,2}$, C.L. Ribeiro Júnior ${ }^{1,2,4}$, \\ B.M. Bordin ${ }^{1,2,3}$ and K.K.V.O. Moura ${ }^{1,2,3}$ \\ ${ }^{1}$ Departamento de Biologia, Núcleo de Pesquisas Replicon, \\ Pontifícia Universidade Católica de Goiás, Goiânia, GO, Brasil \\ ${ }^{2}$ Programa de Pós-Graduação Stricto Sensu, Goiânia, GO, Brasil \\ ${ }^{3}$ Departamento de Biomedicina, Pontifícia Universidade Católica de Goiás, \\ Goiânia, GO, Brasil \\ ${ }^{4}$ Centro de Medicina Fetal e Reprodução Humana - FÉRTILE, Goiânia, \\ GO, Brasil \\ Corresponding author: A.M. Barbosa \\ E-mail: andreiamarcelino_@hotmail.com
}

Genet. Mol. Res. 15 (3): gmr.15038389

Received January 7, 2016

Accepted March 18, 2016

Published August 26, 2016

DOI http://dx.doi.org/10.4238/gmr.15038389

Copyright (C) 2016 The Authors. This is an open-access article distributed under the terms of the Creative Commons Attribution ShareAlike (CC BY-SA) 4.0 License.

ABSTRACT. Endometriosis is a disease that affects 10 to $15 \%$ of the women of reproductive age. It is characterized by the presence of endometrial-like tissues outside of the uterus. Some definitions claim that the functional ectopic tissue is sensitive to the action of hormones. Severity of endometriosis is defined according to a system proposed by the American Society for Reproductive Medicine, which is based on laparoscopic findings. A large number of genetic polymorphisms has been reported for CYP1A1, the gene that is responsible for enzymes 
involved in stage I detoxification of xenobiotics; this gene is located at $15 \mathrm{q} 22-24$, and encodes an isoenzyme that catalyzes the oxidation of polycyclic aromatic hydrocarbons present in phenolic compounds and epoxides. The aim of this study was to analyze the frequency of the $M s p$ I polymorphism and its relation to endometriosis. We obtained peripheral blood samples from 52 women with endometriosis (confirmed by laparoscopy) as well as 42 women without endometriosis (control group). In the case group, the women were between 25 and 35 years of age; the age range was between 25 and 57 years old in the control group. Molecular analysis was performed by polymerase chain reaction. We found a significant association $(\mathrm{P}=0.039)$ between the polymorphic allele $\mathrm{m} 1$ and endometriosis $(32.70 \%)$. In conclusion, this study showed that the $\mathrm{m} 1$ polymorphism is associated with endometriosis, and that $\mathrm{W} 1 / \mathrm{m} 1$ and $\mathrm{m} 1 / \mathrm{m} 1$ polymorphisms are more frequently observed in patients with infertility and severe endometriosis.

Key words: Endometriosis; CYP1A gene; MspI polymorphism; Infertility

\section{INTRODUCTION}

Endometriosis is a disease that affects women of reproductive age. This disease is characterized by the presence of endometrial-like tissues (endometrial or stromal glands) outside the uterus, which are also sensitive to the actions of hormones. Endometriosis affects 10 to $15 \%$ of women of reproductive age (Guo and Wang, 2006; Abrão et al., 2007; Podgaec et al., 2007).

The most common type of endometriosis occurs in the pelvis, but can also be found in other places such as the central nervous system, the thorax, the urinary tract, the gastrointestinal tract, the extremities and skin tissues, the Pouch of Douglas (behind the uterus), the rectovaginal septum (the tissue between the vagina and the rectum), the Fallopian tubes, the ovaries, the bladder and ligaments, the liver, the spleen, the intestines, and the heart. The major symptoms for this disease are dysmenorrhea, dyspareunia, pelvic pain, and infertility (Abrão, 2000; Podgaec et al., 2007).

The first studies on endometriosis in the last century have been conducted by Sampson in 1927. Based on his clinical experience, Sampson proposed retrograde menstruation as the most probable cause of endometriosis. It was suggested that during menstrual flow, some viable endometrial cells exit the Fallopian tubes and attach to the peritoneal surface, where it can invade the tissue as endometriosis. In addition to this direct transport of cells, this process can also occur via blood, lymph channels, or during surgical wound healing (Kistner, 1983; Bankowski, 2006).

Endometriosis can be diagnosed by histopathology, but laparoscopy is considered the gold standard to confirm the diagnosis (Abrão et al., 2007).

Severity of endometriosis is classified by the American Fertility Society (1985). Disease is considered minimal if only peritoneal spots are present; mild extensive peritoneal spots or adhesions are observed; moderate if the disease is characterized by deep endometriomas; and severe if it shows posterior cul-de-sac obliteration.

The endometriosis classification system is based on the size and depth of ovarian or peritoneal implants, the presence, extent, and type of adhesions, and the degree of cul-de-sac obliterations. For example, in light endometriosis, the ovaries have surface implants without

Genetics and Molecular Research 15 (3): gmr.15038389 
endometriosis, scar tissues, or pre-ovarian adhesions (Donadio, 2001).

The risk of endometriosis development for women is approximately $0.6-2.0 \%$. This is increased by seven times (4.3-6.9\%) if they have first-degree relatives with endometriosis. Genetic predisposition does not seem to play a role in endometriosis; however, some authors have proposed that some specific polymorphisms may be associated with the disease (Kennedy et al., 1995; Arvanitis et al., 2001).

There are many studies indicating that cell detoxification is carried out by enzymes that regulate cell protection. They show that inactivation of such xenobiotics and endogenous toxins enable the preservation of cellular integrity while at the same time inhibit cytotoxic events caused by these substances, which may lead to diseases like endometriosis (Wilkinson and Clapper, 1997).

Detoxification enzymes are classified into two groups based on their functional properties. Phase I enzymes activate the xenobiotics in a more electrophilic state, making them more reactive. Phase II enzymes generally activate following phase I reactions, and inhibit the formation of electrophilic products. In addition, they catalyze the conversion of electrophilic chemicals into inactive conjugates, making them more soluble to facilitate their excretion (Wilkinson and Clapper, 1997).

The best-known examples of phase I/activation enzymes are members of the cytochrome P450 (CYPs) superfamily, which are classified as oxidative enzymes. The most studied phase II enzymes belong to the glutathione-S-transferase superfamily (Cascorbi, 2006).

CYP1A1(OMIM: 108330) is a very important gene for the metabolism of carcinogens. It is located on the long arm of chromosome 15 (15q22-24), and there are several patterns for this gene. The restriction enzyme $M s p \mathrm{I}$ is produced by a $\mathrm{T} \rightarrow \mathrm{C}$ in the non-coding region 3', resulting in a polymorphic allele named $\mathrm{m} 1$ (Walker, 1996).

It can be used as a cancer biomarker especially in tumors related to smoking habits, since it is an isoenzyme that catalyzes the oxidation of polycyclic aromatic hydrocarbons into phenolic products and epoxides. This fact suggests that the gene is highly polymorphic due to a thymine/cytosine punctual mutation in the restriction site of MspI. High levels of this enzyme would result in a high capacity to activate polycyclic aromatic hydrocarbons, producing highly reactive electrophilic intermediates that could lead to DNA damage (Cascorbi, 2006).

The aim of this study was to analyze the frequency of the MspI polymorphism and its relation to endometriosis.

\section{MATERIAL AND METHODS}

In this study, 94 samples of $10 \mathrm{~mL}$ peripheral blood were collected to perform molecular and genetic analyses. The samples were divided into two groups: 52 group I samples were obtained from patients with endometriosis, as confirmed by laparoscopy. This group was further subdivided into 2 subgroups (A and B). Patients in subgroup A (24) complained of infertility and intended to become pregnant; patients in subgroup B (28) did not intend to become pregnant. The inclusion criterion for women in the study was laparoscopic confirmation of endometriosis; those with negative results were excluded. The second group (control) consisted of 42 healthy women without any clinical signs of endometriosis; invasive laparoscopy was not performed in these individuals. The project was approved by the Research Ethics Committee in PUC Goiás (Brazil), and written informed consents were obtained from patients prior to enrolment into the study (0126.0.168.000-08).

Following laparoscopic examination, patients with endometriosis were classified

Genetics and Molecular Research 15 (3): gmr.15038389 
according to the degree of endometriosis: stage I (minimum), stage II (mild), stage III (moderate), and stage IV (severe).

DNA was extracted from blood using the Wizard genomic DNA purification (Promega ${ }^{\circledR}$ ) kit, according to manufacturer instructions. The integrity of the DNA was visualized using a $2 \%$ agarose gel.

PCR-RFLP was carried out to detect specific allelic polymorphisms of the CYP1A1m1 gene. Reactions were carried out in a final volume of $25 \mu \mathrm{L}$. The amplified DNA products were subjected to electrophoresis on a $2 \%$ agarose gel, and a voltage of $10 \mathrm{~V} / \mathrm{cm}$ was applied. The DNA bands were stained with ethidium bromide $(5 \mu \mathrm{g} / \mathrm{mL})$, and were analyzed using the VDS $^{\circledR}$ system (Amersham Biosciences, USA). The experiments were performed in duplicate (Carstensen et al., 1993).

PCR-RFLP with CYP1A1 resulted in a 340-bp amplification product in the wild-type genotype $(\mathrm{W} 1 / \mathrm{W} 1)$. A single band was produced, because it was not excised by the restriction enzyme MspI. The homozygous mutant genotype $(\mathrm{m} 1 / \mathrm{m} 1)$ contains a cutting site for the restriction enzyme MspI. As a result, two bands (200 and $140 \mathrm{bp}$ ) were produced. The heterozygous genotype (W1/m1) yielded three bands at 340, 200, and $140 \mathrm{bp}$ (Carstensen et al., 1993).

Data were analyzed using statistical calculations of averages and standard deviations, and the Mann-Whitney U-test was used in order to identify significant differences between groups. Frequency analysis was carried out using the chi-square test. The results were analyzed using the statistical program BioEstat ${ }^{\circledR} 5.0$ (Sociedade Civil Mamirauá/MCT - CNPq). Differences were considered to be significant when $\mathrm{P} \leq 0.05$.

\section{RESULTS}

The age range of patients (Table 1) with endometriosis was between 25 and 35 years, with an average of $30.23 \pm 2.92$ years. In the control group, ages ranged between 25 and 57 years, with an average of $37.38 \pm 11.36$ years. Interestingly, the average age in the control group was almost four times that of the patient group $(\mathrm{P}=0.0004)$.

The genotype frequencies of CYP1A1 in patients with endometriosis (Table 2) for the homozygous wild-type (W1/W1), the heterozygous genotype (W1/m1), and the mutant genotype $(\mathrm{m} 1 / \mathrm{m} 1)$ were $67.31 \%(35 / 52), 28.84 \%(15 / 52)$, and $3.85 \%(2 / 52)$, respectively. The genotype frequencies of CYP1A1 in the control group for W1/W1, W1/m1, and $\mathrm{m} 1 / \mathrm{m} 1$ were $85.71 \%(36 / 42), 14.29 \%(6 / 42)$, and $0 \%$, respectively. The results demonstrated that the frequencies of the polymorphic genotypes $\mathrm{W} 1 / \mathrm{m} 1$ and $\mathrm{m} 1 / \mathrm{m} 1$ were significantly higher in patients with endometriosis as compared with the controls.

\section{Table 1. Average age in patients with endometriosis and controls.}

\begin{tabular}{l|c|c|c|c}
\hline Group & $\mathrm{N}$ & Average & SD & P value \\
\hline Endometriosis patients & 52 & 30.23 & 2.92 & \\
\hline Controls & & & & 0.0004 \\
\hline
\end{tabular}

Analysis performed using the Mann-Whitney U-test.

As shown in Table 3, the frequency of the wild-type allele W1 in CYP1A1m1 was $67.30 \%$ in the endometriosis patients (70/104); the mutant allele (m1) frequency was $32.70 \%$ (34/104). In the control subjects, the wild-type (W1) allele frequency was $85.71 \%(72 / 84)$; the 
$\mathrm{m} 1$ allele (mutant) frequency was $14.29 \%(12 / 84)$. These results suggested that the frequencies of mutant alleles (m1) were higher in women with endometriosis as compared to the control group $(\mathrm{P}=0.006)$

Table 2. Genotype frequencies of CYP1A1 in the endometriosis and control groups.

\begin{tabular}{l|c|c|c}
\hline Genotype & Endometriosis [(N) \%] & Control [(N) \%] & P \\
\hline W1/W1 & $(35) 67.31$ & $(36) 85.71$ & 0.087 \\
\hline $\mathrm{W} 1 / \mathrm{m} 1$ & $(15) 28.84$ & $(6) 14.29$ & $(0) 0$ \\
\hline $\mathrm{m} 1 / \mathrm{m} 1$ & $(2) 3.85$ & $(42) 100$ & \\
\hline Total & $(52) 100$ & & \\
\hline
\end{tabular}

Analysis performed using the chi-square test.

Table 3. Allele frequencies of $C Y P 1 A 1$ in the endometriosis and control groups.

\begin{tabular}{l|c|c|c}
\hline Allele & Endometriosis $[(\mathrm{N}) \%]$ & Control $[(\mathrm{N}) \%]$ & P value \\
\hline $\mathrm{W} 1$ & $(70) 67.30$ & $(72) 85.71$ & 0.006 \\
\hline $\mathrm{m} 1$ & $(34) 32.70$ & $(12) 14.29$ & \\
\hline Total & $(104) 100$ & $(84) 100$ & \\
\hline
\end{tabular}

Analysis performed using the chi-square test.

The genotype frequencies of CYP1A1 (Table 4) in endometriosis type I/II patients were as follows: $68.19 \%(15 / 22)$ of the patients were W1/W1, 31.81\% $(7 / 22)$ were $\mathrm{W} 1 / \mathrm{m} 1$, and $0 \%(0.0 / 22)$ was $\mathrm{m} 1 / \mathrm{m} 1$. For class III/IV patients, $66.67 \%(20 / 30), 26.66 \%(8 / 30)$, and $6.67 \%(2 / 30)$ of the patients corresponded to the $\mathrm{W} 1 / \mathrm{W} 1, \mathrm{~W} 1 / \mathrm{m} 1$, and $\mathrm{m} 1 / \mathrm{m} 1$ genotypes, respectively. However, the frequencies of $\mathrm{m} 1 / \mathrm{m} 1$ and $\mathrm{W} 1 / \mathrm{m} 1$ were not significantly different between class III/IV patients and class I/II patients $(\mathrm{P}=0.452)$.

Table 4. Genotype distribution of CYPIAl in endometriosis patients (class I/II, class III/IV).

\begin{tabular}{l|c|c|c|c}
\hline \multirow{2}{*}{ Endometriosis group } & \multicolumn{4}{|c}{ Genotype } \\
\cline { 2 - 5 } & $\mathrm{W} 1 / \mathrm{W} 1[(\mathrm{~N}) \%]$ & $\mathrm{W} 1 / \mathrm{m} 1[(\mathrm{~N}) \%]$ & $\mathrm{m} 1 / \mathrm{m} 1[(\mathrm{~N}) \%]$ & $(0) 0$ \\
\hline Class I/II $(\mathrm{N}=22)$ & $(15) 68.19$ & $(7) 31.81$ & $(2) 6.67$ & 0.452 \\
\hline Class III/IV $(\mathrm{N}=30)$ & $(20) 66.67$ & $(8) 26.66$ & value \\
\hline
\end{tabular}

Analysis performed using the chi-square test.

The genotype frequencies of CYP1A1m1 (Table 5) in type I/II patients showed that for this class of the disease $68.19 \%(30 / 44)$ of the patients were W1/W1, 31.81\% (14/44) were $\mathrm{W} 1 / \mathrm{m} 1$, and $0.0 \%(0 / 44)$ was genotype $\mathrm{m} 1 / \mathrm{m} 1$. For class III/IV patients with alleles W1/W1 were $66.67 \%(40 / 60), 26.66 \%(16 / 60)$ for $\mathrm{W} 1 / \mathrm{m} 1$ and $6.67 \%(04 / 60)$ for $\mathrm{m} 1 / \mathrm{m} 1$. The frequencies of polymorphic alleles $\mathrm{W} 1 / \mathrm{m} 1$ and $\mathrm{m} 1 / \mathrm{m} 1$ are more frequent in patients with endometriosis according to the class III or IV compared to patients class I/II, thus the difference is not significant, $\mathrm{P}=0.204$.

Table 5. Allele frequencies of CYP1A1 in endometriosis patients (class I/II, class III/IV).

\begin{tabular}{|c|c|c|c|c|}
\hline \multirow[t]{2}{*}{ Endometriosis group } & \multicolumn{4}{|c|}{ Genotype } \\
\hline & $\mathrm{W} 1 / \mathrm{W} 1[(\mathrm{~N}) \%]$ & $\mathrm{W} 1 / \mathrm{ml}[(\mathrm{N}) \%]$ & $\mathrm{m} 1 / \mathrm{ml}[(\mathrm{N}) \%]$ & $\mathrm{P}$ value \\
\hline Class I/II $(\mathrm{N}=44)$ & (30) 68.19 & (14) 31.81 & $(0) 0$ & 0.204 \\
\hline Class III/IV $(\mathrm{N}=60)$ & (40) 66.67 & (16) 26.66 & (4) 6.67 & \\
\hline
\end{tabular}

Analysis performed using the chi-square test.

Genetics and Molecular Research 15 (3): gmr.15038389 
The genotype frequencies of polymorphism in the CYP1A1 gene in the fertile patients are shown in Table 6: homozygous wild-type (W1/W1) was 79.16\% (19/52), heterozygote (W1/ $\mathrm{m} 1$ ) was $16.67 \%(4 / 52)$, and homozygous mutant $(\mathrm{m} 1 / \mathrm{m} 1)$ was $4.17 \%(1 / 52)$. The genotype frequencies in infertile patients with endometriosis were as follows: homozygous wild-type (W1/W1) was $55.56 \%(15 / 27)$, heterozygous $\mathrm{W} 1 / \mathrm{m} 1$ was $40.74 \%(11 / 27)$, homozygous mutant $\mathrm{m} 1 / \mathrm{m} 1$ was $3.70 \%(1 / 27)$.

Table 6. Frequencies of CYP1A1 genotype among cases (endometriosis) (fertile and infertile patients) and
controls.
\begin{tabular}{l|c|c|c|c}
\hline Genotype & Fertile $[(\mathrm{N}) \%]$ & Infertile $[(\mathrm{N}) \%]$ & Control $[(\mathrm{N}) \%]$ & P value \\
\hline $\mathrm{W} 1 / \mathrm{W} 1$ & $(19) 79.16$ & $(15) 55.56$ & $(36) 85.72$ & \\
\hline $\mathrm{W} 1 / \mathrm{m} 1$ & $(4) 16.67$ & $(11) 40.74$ & $(6) 14.28$ & $(0) 0$ \\
\hline $\mathrm{m} 1 / \mathrm{m} 1$ & $(1) 4.17$ & $(1) 3.70$ & $(42) 100$ & \\
\hline Total & $(24) 100$ & $(27) 100$ & 05 \\
\hline
\end{tabular}

Analysis performed using the chi-square test.

In control subjects, the genotype frequency of homozygous wild-type (W1/W1) was $85.72 \%(36 / 42)$, the frequency of $\mathrm{W} 1 / \mathrm{m} 1$ was $14.28 \%(6 / 42)$, and the frequency of homozygous mutant $(\mathrm{m} 1 / \mathrm{m} 1)$ was $0 \%(0 / 42)$. The genotype frequencies of the mutant genotype were found to be significantly higher in the infertile patients than in fertile subjects.

To reassess the results of this study, a sensitivity test was conducted. We found the result to be $70 \%$ in patients with endometriosis with a specificity value of $37 \%$. The positivepredictive value was $36 \%$, and the negative-predictive value was $42 \%$. Based on the results, we conclude that the CYP1A1m 1 gene is an important biomarker for endometriosis, and may enhance our understanding of pre-dispositions to endometriosis.

\section{DISCUSSION}

This study analyzed endometriosis patients between 25 and 35 years of age. The average age of patients with increased risk of infertility was found to be 30.23 years. These results were in accordance with the study by Moura et al. (1999), who reported that the average age at which a diagnosis of endometriosis is established is around 31 years. In addition, Pritts and Taylor (2003) reported that the average age for the diagnosis of endometriosis is 28 years. The analysis of subjects without endometriosis (control group) revealed an average age of 37.38 years, which was significantly older than that of the patient group. Results from this study revealed an association between endometriosis and the $\mathrm{m} 1$ allele; two patients with endometriosis were demonstrated to have the homozygous mutant genotype. Nakata et al. (2004) analyzed 25 patients with endometriosis and 25 without the disease (control group). The allele frequencies obtained from the two groups indicated no association between the polymorphic CYP $1 A 1 \mathrm{~m} 1$ allele and endometriosis. We found that the mutant allele frequency was higher in women with endometriosis when compared to the control group. However, this difference was not significant. A study conducted in 310 Indian women with endometriosis and 215 controls found no association between endometriosis and CYP1A1 gene polymorphisms (Babu et al., 2005).

The study also revealed that the genotypes $(\mathrm{m} 1)$ were not associated with the severity of the disease. There were no differences in genotype frequencies between class I/II patients and class III/IV patients. However, the $\mathrm{m} 1$ genotype frequencies were higher in patients with

Genetics and Molecular Research 15 (3): gmr.15038389 
severe endometriosis. Similar results were also found in fertile women with endometriosis. This suggested that CYP1Al gene polymorphisms may also influence disease progression.

\section{Conflicts of interest}

The authors declare no conflict of interest.

\section{ACKNOWLEDGMENTS}

A.M. Barbosa and K.K.V.O. Moura acknowledge the contribution of this article for executable rights of Pontifícia Universidade Católica de Goiás, Goiânia, Brazil (PUCGO/PROPE/Mgene). We are grateful to Centro de Medicina Fetal e Reprodução Humana (FÉTILE) and Departamento de Biologia, Núcleo de Pesquisas Replicon (PUC-GO), Goiânia, Goiás, Brazil, which enabled us to conduct this research and support.

\section{REFERENCES}

Abrão MS (2000). In: Endometriose, uma visão contemporânea. $1^{\mathrm{a}}$ ed. Revinter, Rio de Janeiro, 257-235.

Abrão MS, Podgaec S and Dias Jr JÁ (2007). Endometriose, a mulher moderna e o Brasil. Prat. Hosp. 50: 73-77.

American Fertility Society (1985). Revised American Fertility Society classification of endometriosis: 1985. Fertil. Steril. 43: 351-352. http://dx.doi.org/10.1016/S0015-0282(16)48430-X

Arvanitis DA, Goumenou AG, Matalliotakis IM, Koumantakis EE, et al. (2001). Low-penetrance genes are associated with increased susceptibility to endometriosis. Fertil. Steril. 76: 1202-1206. http://dx.doi.org/10.1016/S0015$\underline{0282(01) 02865-5}$

Babu KA, Reddy NG, Deendayal M, Kennedy S, et al. (2005). GSTM1, GSTT1 and CYP1A1 detoxification gene polymorphisms and their relationship with advanced stages of endometriosis in South Indian women. Pharmacogenet. Genomics 15: 167-172. http://dx.doi.org/10.1097/01213011-200503000-00005

Bankowski BJ (2006). Infertility and Assisted Reproductive Technologies. In: The Johns Hopkins manual of gynecology and obstetrics. 2nd edn (Hearne AE, Lambrou NC, Fox HE and Wallah EE, eds.). Lippincott Williams \& Wilkins, Philadelphia, 31: 157-159.

Carstensen U, Alexandrie AK, Högstedt B, Rannug A, et al. (1993). B- and T-lymphocyte micronuclei in chimney sweeps with respect to genetic polymorphism for CYP1A1 and GST1 (class Mu). Mutat. Res. 289: 187-195. http://dx.doi. org/10.1016/0027-5107(93)90069-R

Cascorbi I (2006). Genetic basis of toxic reactions to drugs and chemicals. Toxicol. Lett. 162: 16-28. http://dx.doi. org/10.1016/j.toxlet.2005.10.015

Donadio N (2001). In: Consenso Brasileiro em Videoendoscopia Ginecológica. Artes Médicas, São Paulo.

Guo SW and Wang Y (2006). Sources of heterogeneities in estimating the prevalence of endometriosis in infertile and previously fertile women. Fertil. Steril. 86: 1584-1595.http://dx.doi.org/10.1016/j.fertnstert.2006.04.040

Kennedy S, Mardon H and Barlow D (1995). Familial endometriosis. J. Assist. Reprod. Genet. 12: 32-34. http://dx.doi. org/10.1007/BF02214126

Kistner RW (1983). In: Tratado de Ginecologia Segunda Edição. Ediciones Toray, Barcelona, 830.

Moura MD, Negreiros TP, Nogueira AA, Ferriani RA, et al. (1999). Avaliação do Tratamento Clínico da Endometriose. Rev. Bras. Ginecol. Obstet. 21: 85-90. http://dx.doi.org/10.1590/S0100-72031999000200005

Nakata LC, Goloni-Bertollo EM, dos Santos I, Oliani AH, et al. (2004). Biomarcadores de Susceptibilidade à Endometriosis. Rev. Bras. Ginecol. Obstet. 26: 299-304. http://dx.doi.org/10.1590/S0100-72032004000400006

Podgaec S, Abrão MS, Dias Jr JA, Rizzo LV, et al. (2007). Endometriosis: an inflammatory disease with a Th2 immune response component. Hum. Reprod. 22: 1373-1379. http://dx.doi.org/10.1093/humrep/del516

Pritts EA and Taylor RN (2003). An evidence-based evaluation of endometriosis-associated infertility. Endocrinol. Metab. Clin. North Am. 32: 653-667. http://dx.doi.org/10.1016/S0889-8529(03)00045-8

Sampson JA (1997). Peritoneal endometriosis due to the menstrual dissemination of endometrial tissue into the peritoneal cavity. Am. J. Obstet. Gynecol. 14: 422-469. http://dx.doi.org/10.1016/S0002-9378(15)30003-X

Walker CL (1996). Cancer susceptibility genes and molecular carcinogenesis. American Association for Cancer Research Special Conference: Cancer Susceptibility Genes and Molecular Carcinogenesis. Mol. Med. Today 2: 364-365. http:// dx.doi.org/10.1016/S1357-4310(96)30076-2

Wilkinson 4th J and Clapper ML (1997). Detoxication enzymes and chemoprevention. Proc. Soc. Exp. Biol. Med. 216: 192-200. http://dx.doi.org/10.3181/00379727-216-44169

Genetics and Molecular Research 15 (3): gmr.15038389 